\title{
Modelling flood regulation ecosystem services dynamics based on climate and land use information
}

\begin{abstract}
The concept of ecosystem service (ES) identifies benefits that people obtain from ecosystems with contributions to human well-being. One important ES under external pressure is "flood regulation" that describes an ecosystem's capacity to reduce flood hazards.

Several related studies estimate current flood regulation ES. However, regional climate projections indicate a shift in precipitation patterns. Therefore, Climate and land use changes make it necessary to assess future supply in order to test functionality and adaptation measures. This study focuses on surface retention ES. We used two methods to show the relevance of different landscape scenarios and climate information for flood regulation ES supply: 1) hydraulic simulations with the model HECRAS 2) the flood retention capacity indicator suggested by the German MAES-Working group. We simulated two events: the historic flood of 2013 and future hypothetically 10\% higher water levels. Furthermore, three land use change scenarios were evaluated.

The model results indicate water accumulation by vegetation. Higher water levels of future climate scenarios lead to an increase in flooded areas and higher water volumes. To evaluate flood regulation capacities, an approach solely based on 2D retention areas, such as the MAESindicator, is not sufficient. Modelling approaches deliver the opportunity for future scenario simulations.
\end{abstract}

Keywords:

MAES, Indicator, HEC-RAS, Scenarios, Nature-based Solutions

\author{
Thea Wübbelmann ${ }^{1,2^{*}}$, Steffen \\ Bender $^{1}$, Benjamin Burkhard ${ }^{2,3}$ \\ ${ }^{1)}$ Climate Service Center Germany \\ (GERICS), Helmholtz-Zentrum \\ Geesthacht (HZG), Hamburg, \\ Germany \\ 2) Leibniz University Hannover, \\ Institute of Physical Geography \\ and Landscape Ecology, Hannover, \\ Germany \\ 3) Leibniz Centre for Agricultural \\ Landscape Research ZALF, \\ Müncheberg, Germany \\ *Corresponding author: Thea \\ Wübbelmann, Climate Service \\ Center Germany (GERICS), \\ Helmholtz-Zentrum Geesthacht \\ (HZG), Fischertwiete 1; 20095 \\ Hamburg, Germany, Email: thea. \\ wuebbelmann@hzg.de
}




\section{Introduction}

The loss and degradation of biodiversity and ecosystems is one of the main global risks (WEF 2019). Changes in land use, climate conditions and matter fluxes are key pressures for biodiversity loss (Baessler and Klotz 2019). However, the supply of ecosystem services (ES) must be ensured in order to safeguard the direct and indirect contributions of ecosystems to human well-being (MEA 2005; Burkhard and Maes 2017; TEEB 2010). The concept of ES links social and environmental systems to achieve a sustainable use of natural resources (Engel and Schaefer 2013; Burkhard and Maes 2017) and helps to discover synergies and trade-offs between different ES (Liu et al. 2013; Engel and Schaefer 2013).

To assess one of the most important pressures (“ [...] pressure [...] as a result of a driver-initiated mechanism (human activity/ natural process) causing an effect on any part of an ecosystem that may alter the environmental state" (Oesterwind et al. 2016, p. 11) for local and regional loss of biodiversity, increase in natural disasters and extreme events, it is becoming increasingly important to focus on changing climate parameters (WEF 2019). These changes influence many components of the water cycle and thus, flood characteristics. Because of a worldwide observed rise in flood events that also increasingly impacts people (Swiss Re Institute 2019), flood regulation ES are becoming more important (Paprotny et al. 2018; WEF 2019). Regional climate information can provide significant information (Jacob et al. 2014) to support the assessment of flood regulation ES.

\subsection{Flood regulation ES and related indicators}

„Flood regulation ES supply “addresses the ecosystem's capacity to lower flood hazards caused by heavy precipitation events by reducing the runoff fraction" (Stürck et al. 2014, p.198) and thus reduces potential economic and social damages (Vallecillo et al. 2019; Müller et al. 2016). Usually, it is determined by the water retention function of terrain, soil or vegetation. Main pressures for flood retention loss are changes of land use and climate conditions. With regard of these pressures, the reduction of retention areas and the modification of water-related functions such as evapotranspiration, vegetation-soil interactions and surface roughness, and with that flow rates and flow velocity, are important varied processes. As a consequence, the annual water availability changes which can lead to periods of water scarcity and an increase in flood risk and water pollution (Engel and Schaefer 2013).

To quantify ecosystem service supply, indicator-based approaches are commonly applied, using different parameters and dimensions (Vigerstol and Aukema 2011; Stürck et al. 2014). The initiative "Mapping and Assessment of Ecosystem and their Services" (MAES) has gained increasing importance in the context of the EU Biodiversity Strategy 2020 (European Commission 2011). In Germany, the national MAES working group has developed an area-based indicator for the evaluation of the surface flood retention capacity of floodplains (Grunewald et al. 2016; Albert et al. 2015), which was analysed for the practicability compared to results from hydraulic models in this study. De Groot et al. (2010) proposed a water volume-based assessment that considers the water storage capacity including the retention capacity in the soil or at surface depressions. Logsdon and Chaubey (2013) used a three-component function to estimate flood regulation, based on the flood duration [days], the number of flooding events per time period and the average magnitude $\left[\mathrm{m}^{3} / \mathrm{s}\right]$ of the flood. In the past, model-based approaches of various complexity have become more common, for example to improve the consideration of complex physical processes. While hydrological models deliver more detailed results related to the involved processes, special ES tools (e.g. InVEST (Sharp et al. 2018) and ARIES (ARIES n.d.) are more accessible also to non-experts and can reflect trade-offs between ES (Vigerstol and Aukema 2011). Another method is to combine hydrological parameters of model results (e.g. infiltration, surface runoff, peak flow) with landscape information (e.g. land use, soil types) for spatial analysis (Nedkov and Burkhard 2012). Most of the studies analyse the flood regulation capacities for current climate conditions. Gaglio et al. (2019) have considered climate change with InVest, referring to the increasing drought in a catchment area in Portugal. With regard to the mentioned pressures, it is necessary to include regional climate projections for the next decades to estimate ES functionality in the future. 


\subsection{Climate change as pressures of ES changes}

The carbon emissions, caused by human activities such as fossil fuel burning or land use change, have a high impact on the global climate that affect ecosystem condition and ES supply (IPCC 2013, 2019). Future climate projections are based on ensembles of dynamic and statistic regional climate models with different emission scenarios (Representative Concentration Pathways (RCP)), driven by anthropogenic radiation propulsion (Moss et al. 2010; Bender and Jacob 2016; Bender and Bülow 2018). Three classes of pathway emission scenarios are commonly used: RCP2.6 ("climate protecting") low emission scenario, reduction of the greenhouse gas emissions; RCP4.5 ("moderate emission scenario"); RCP8.5 ("business-as-usual scenario") increasing emissions (Moss et al. 2010; DKRZ n.d.; van Vuuren et al. 2011).

Results of regional climate projections indicate a robust and significant temperature increase for all scenarios in continental Europe until the end of the 21st century (RCP4.5: $+1.6{ }^{\circ} \mathrm{C}$ to $+3.2{ }^{\circ} \mathrm{C}$; RCP 8.5: $+3.7{ }^{\circ} \mathrm{C}$ to $+5.2^{\circ} \mathrm{C}$ ) (Bender and Bülow 2018; Jacob et al. 2014). As a result, there is a higher potential evaporation (IPCC 2013). Furthermore, an inter-annual shift towards more precipitation and runoff during winter and decreasing summer precipitation months is to be assumed (IPCC 2013; Bender and Jacob 2016) causing higher flood risks in winter season. Regional climate projections for Germany show a local, robust and significant increase of heavy precipitation frequency by about $25 \%$ for the RCP 8.5 (period 2071-2100, reference period 1971-2000) for autumn and winter. For RCP 4.5, no significant changes are obvious (Jacob et al. 2014).

\subsection{Objectives of the study}

Our study focused on the derivation of flood regulation ES by hydraulic modelling for extreme flood events. Hydraulic modelling delivers information on the extent and depth of flooding and therefore on the surface retention capacity of a floodplain. With this method, we investigated the importance of flood regulation ES due to changing climate and land uses. To classify the model results, a simple retention area based indicator of the German MAES-working group was used. The two methods and their results were compared and the limitations and advantages were identified. Following research questions were answered by this study:

- Is HEC-RAS suitable to model flood regulation ES?

- What does the assessment of future flood regulation ES show?

- What are the advantages of flood regulation ES modelling compared to retention area-based indication?

\section{Research area}

The research area $\left(24 \mathrm{~km}^{2}\right)$ is located in the Biosphere Reserve Lower Saxonia Elbe Valley, close to the city of Schnackenburg (Figure 1). The area was chosen because it was flooded several times in the past years. The land use types pastures or grassland (36\%) and farmland (32\%) are dominant. Forest areas cover $13 \%$ and only $2.5 \%$ of the area belong to settlements. The remaining area includes, for example, water bodies. In the entire floodplain, flood deposits of alluvial clay and sands can be found. The main soil types are gleys and pseudogleys (LBEG n.d.; BGR 2013).

The region is characterized by continental and maritime climate conditions. The annual mean temperature (1951-1980) is $8^{\circ} \mathrm{C}$. The maximum temperature is $17^{\circ} \mathrm{C}$ in July and the minimum is $-0.3^{\circ} \mathrm{C}$ in January. The mean annual precipitation at the Station Dömitz amounts to $564 \mathrm{~mm}$ (1961-1990). Precipitation decreases from west to east (BrNE-Management 2009). In winter, snow melting and heavy rainfalls can cause surface water run-offs and river floods. In summer, prolonged precipitation periods lead to high water levels in the Elbe river (Meyer 2017; NLWKN 2017). For the end of the century (2070-2099) relative to 1971 - 2000, regional climate projections show a significant increase of annual temperatures: $0.2-2.0^{\circ} \mathrm{C}(\mathrm{RCP} 2.6), 1.2-3.1^{\circ} \mathrm{C}(\mathrm{RCP} 4.5)$, and 2.6 $-5.0^{\circ} \mathrm{C}$ (RCP8.5) for the region of the Biosphere Reserve Lower Saxonia Elbe Valley. For the projected annual mean precipitation amounts, changes range between -9.9 and $+7.4 \%$ (RCP2.6), -1.7 and +17.2 \% (RCP4.5), and -7.0 and $27.9 \%$ (RCP8.5). These changes are not significant, but show an increasing tendency (Pfeifer et al. 2015). This trend can be at- 


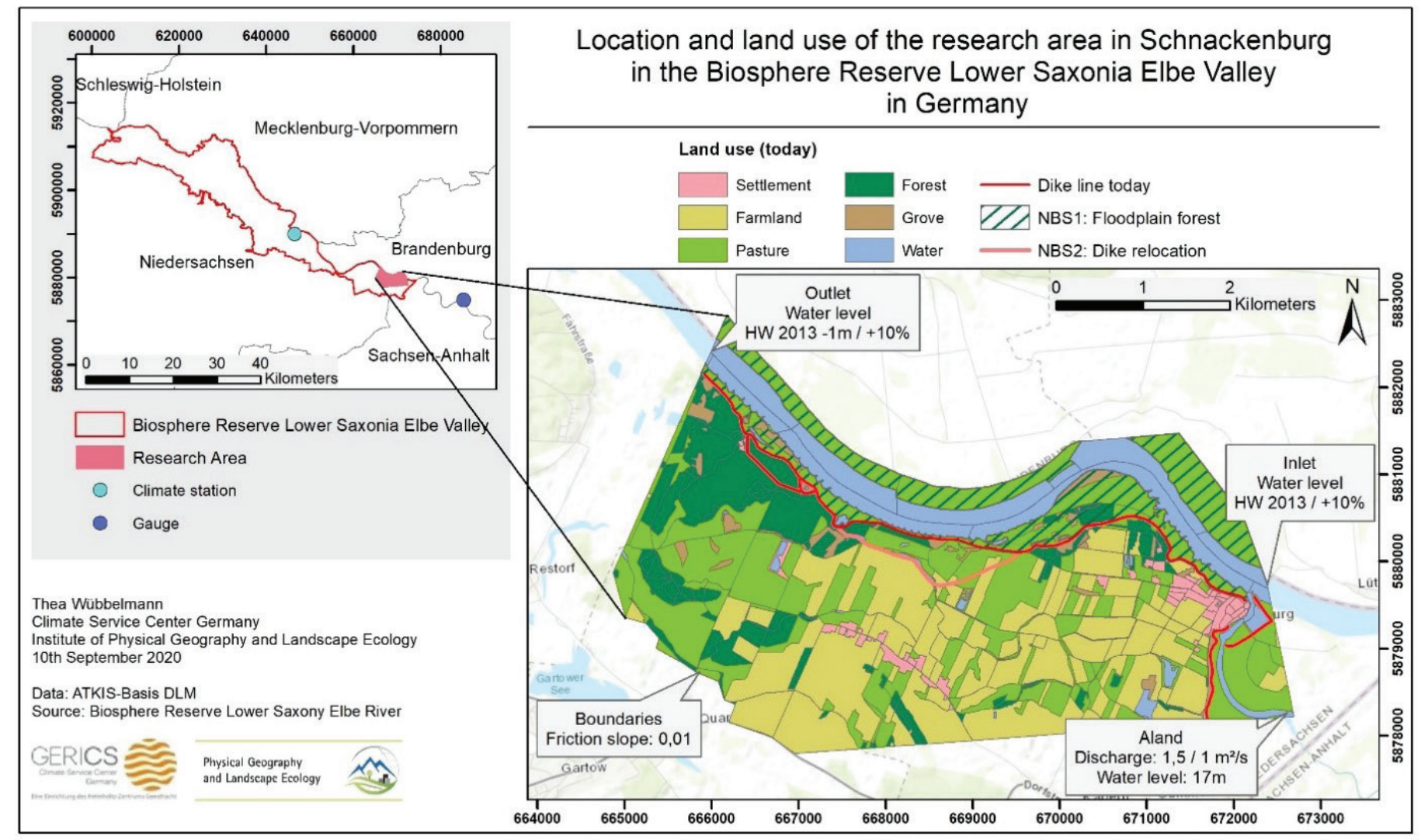

Figure 1. Location and land use of the research area in the Biosphere Reserve Lower Saxonia Elbe Valley in Germany. Also the tested land use scenarios and the boundary conditions for the hydraulic modelling with HEC-RAS are shown.

tributed to projected higher precipitation amounts in the winter half year. While no clear trend can be discerned in summer (Bowyer et al. 2020).

\section{Materials and Methods}

\subsection{Hydraulic Modelling with HEC-RAS}

Hydraulic models simulate the flow, amount and availability of surface water on different scales. They can assess effects of changes, like topography, vegetation and land use or meteorological variations (Sitterson et al. 2017). We used the HEC-RAS model (ㅂydrologic Engineering Centre - River Analysis $\underline{\text { Sys- }}$ tem), developed by the U.S. Army Corp of Engineers. It provides different possibilities for water run-off simulations, for instance two-dimensional unsteady flow simulations. For detailed information see Brunner (2016d, 2016b, 2016a, 2016c).

Basic input data are the geometry of the area (channel cross sections or a digital elevation model (DEM)), the roughness coefficient by Manning derived from land use data, and discharge information. The setup of the modelling with HEC-RAS follows three main steps (Figure 2): 1) setting the geometry, 2) adjusting the unsteady flow analysis, and 3) defining the time steps for the computation and runoff simulation. The boundary conditions of the inlet and outlet as well as the other edges of the research area are shown in Figure 1. The upstream and downstream boundary conditions were based on the discharge measurements of the flood of 2013 at gauge Wittenberge (chapter 3.3; Figure 1). To ensure a flow gradient the water level of the outflow was lowered by $1 \mathrm{~m}$. The future flooding scenario was based on the water levels from the flood of 2013 elevated by $10 \%$, according to projections of future runoff scenarios (Nilson et al. 2014). To consider a high groundwater level because of rainfall and previous high discharge values, the initial water level conditions were set to $16 \mathrm{~m}$ above sea level in the whole research area. For the given computed time steps, single raster data sets were exported to 1) visualize the temporal development of water depths and flooded areas and 2) further processing in GIS. Besides the flood extent 


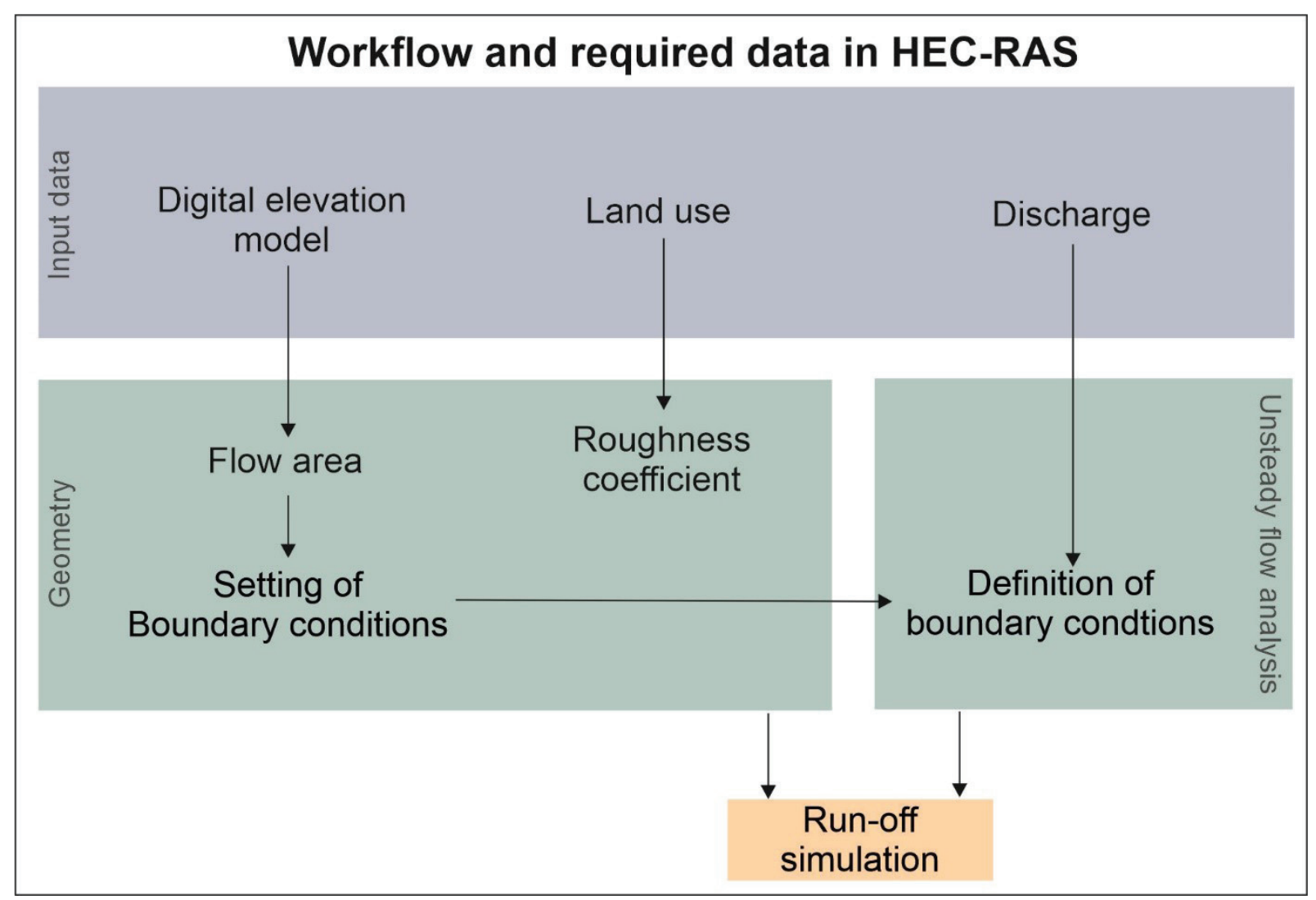

Figure 2. Schematic representation of the workflow in HEC-RAS.

and water depth for estimating the retention capacity, it is also possible to export runoff velocities and sediment transportation from the model.

\subsection{MAES-DE-Indicator: Ecosystem service "Water regulation by floodplains"}

The MAES-DE working group has a focus on floods caused by rivers and therefore developed the ES-indicator "water regulation by floodplains" for the national scale. It describes the capacity of floodplains to absorb surface water, using an simplified area-based retention approach (Grunewald et al. 2016).

The indicator "area for flood retention" (Ger.: "Fläche für Hochwasserretention" (FHR)) is calculated based on the inundation area, that is not protected from flooding by dikes or other measures (equation 1 ). Only non-artificial land areas (e.g. areas with pastures, forests, shrubs and wetlands) are taken into account, whereas settlements and other sealed surfaces are subtracted from the floodplain area (Grunewald et al. 2016; Albert et al. 2015):

$F H R=$ recent floodplain- settlements \& traffic area (Equation 1)
The delimitation of the floodplain area was carried out using the DEM and the dyke line from the land use dataset.

\subsection{Database}

A DEM, land use data and runoff data are needed for the methodological application. Table a in the annex gives a detailed overview of the used data for both approaches, including information about the type of data, spatial resolution and data sources. The modelling with HEC-RAS require a DEM and land use data. The land use data is used to derive the Manning $n$ value as a roughness coefficient (see Table 1 ). In addition, the model needs a run-off dataset. For this study, the discharge data from the summer flood 2013 at the Wittenberge gauge, a few kilometres upstream of Schnackenburg, were used (Figure 3). The event lasted 57 days, from May $5^{\text {th }}$ to July $20^{\text {th }}$, with the maximum discharge on July $10^{\text {th }}$ (discharge: $4250 \mathrm{~m} / \mathrm{s}$; water level: $780 \mathrm{~cm}$ ) (IKSE n.d.). For the future flood scenario, the summer flood event of 2013 was elevated by $10 \%$ to consider a potentially higher extreme event in future. With this adjustment, the maximum discharge on June $10^{\text {th }}$ reaches 
$4700 \mathrm{~m}^{3} / \mathrm{s}$. This value complies with the assumption of Alexy (2014), who used a climate change-causedcaused extreme scenario runoff value of $5000 \mathrm{~m}^{3} / \mathrm{s}$ for another study next to our research area. Other studies such as Nilson et al. (2014) used a projected bandwidth of an annual mean discharge in the Elbe between $-20 \%$ and $+5 \%$ until the end of the $21^{\text {st }}$ century towards the reference period of 1961-1990. Regardless of land use changes and engineering measures in the upstream part of the Elbe catchment, which also have a high impact on the discharge behaviour, our approach represents a "potential future flood scenario".

The indicator-based approach requires respective land use data and topography data to delimit the floodplain area.

\subsection{Land use scenarios}

To compare the effects of different types of land use and land use changes on retention capacity and river discharge, three scenarios were investigated (Figure 1 , Table b). All scenarios can be classified as nature-based solutions (NBS) (WWAP 2018). NBS are nature- and ecosystem-based adaptation measures that are inspired or supported by the characteristics and processes of nature and/or copy, use or imitate these (European Commission 2015; WWAP 2018). The land use scenarios are abbreviated as NBS in the following.
Table 1. Land use in the case study area and their roughness coefficients by Manning (Brunner 2016c).

\begin{tabular}{|l|c|c|c|}
\hline Land use & $\begin{array}{c}\text { Roughness } \\
\text { coefficient by } \\
\text { Manning } \mathbf{n}\end{array}$ & Land use & $\begin{array}{c}\text { Roughness } \\
\text { coefficient by } \\
\text { Manning } \mathbf{~}\end{array}$ \\
\hline Settlement & 0.016 & Forest & 0.1 \\
\hline Farmland & 0.037 & Grove & 0.06 \\
\hline Pasture & 0.03 & Water & 0.045 \\
\hline
\end{tabular}

The current use of the floodplain is listed as NBS 0. The first land use scenario (NBS 1 ) is a floodplain forest. All areas within the floodplain except the water bodies are changed to forests. The second scenario (NBS 2) is a dike relocation on the southern site of the Elbe river. Detailed information and effects of the different scenarios can be found in Table $b$.

\section{Results}

\section{1 HEC-RAS modelling}

Water volume and water area as valuation parameters for the retention capacity

For the valuation of the surface retention capacity derived from the modelling, an area-based and volume-based assessment was made for the study area. Figure 4 shows the comparison of the flooded area ( $x$-axis) and the water volume ( $y$-axis), determined

\section{flood water level}

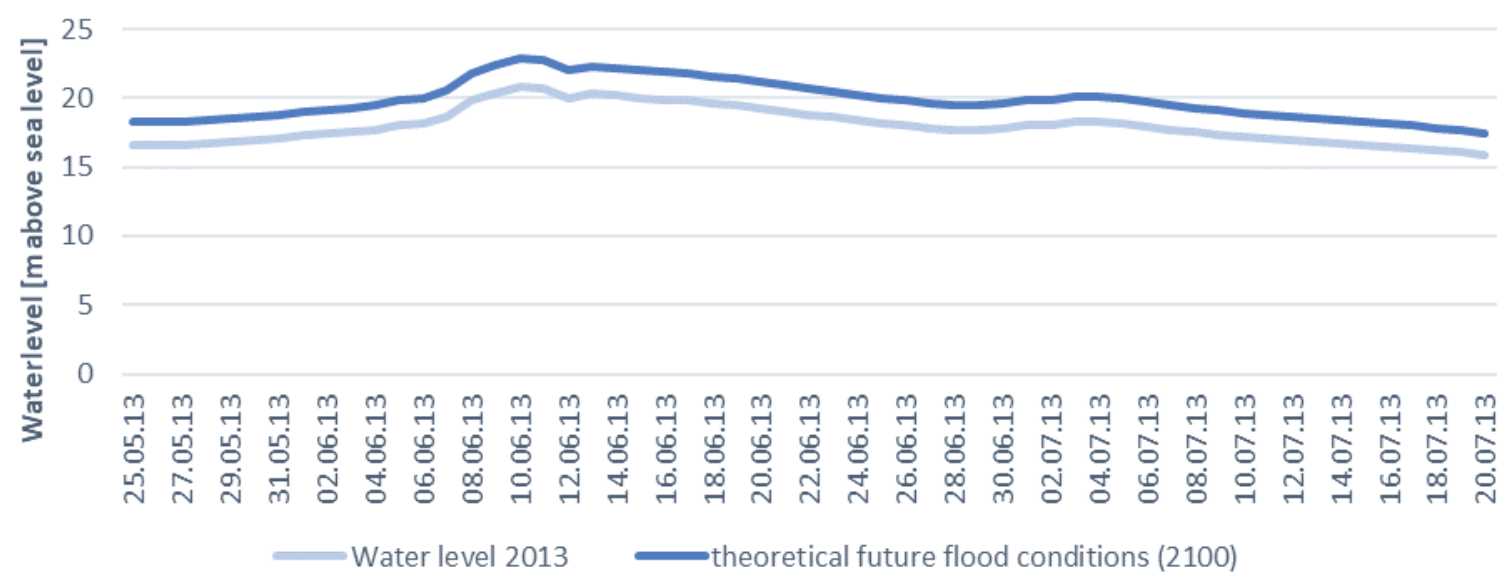

Figure 3. Water level of the summer flood 2013 at the Elbe river near Schnackenburg (IKSE n.d.) and theoretical future flood conditions for the year 2100 (IKSE n.d.; Nilson et al. 2014). 


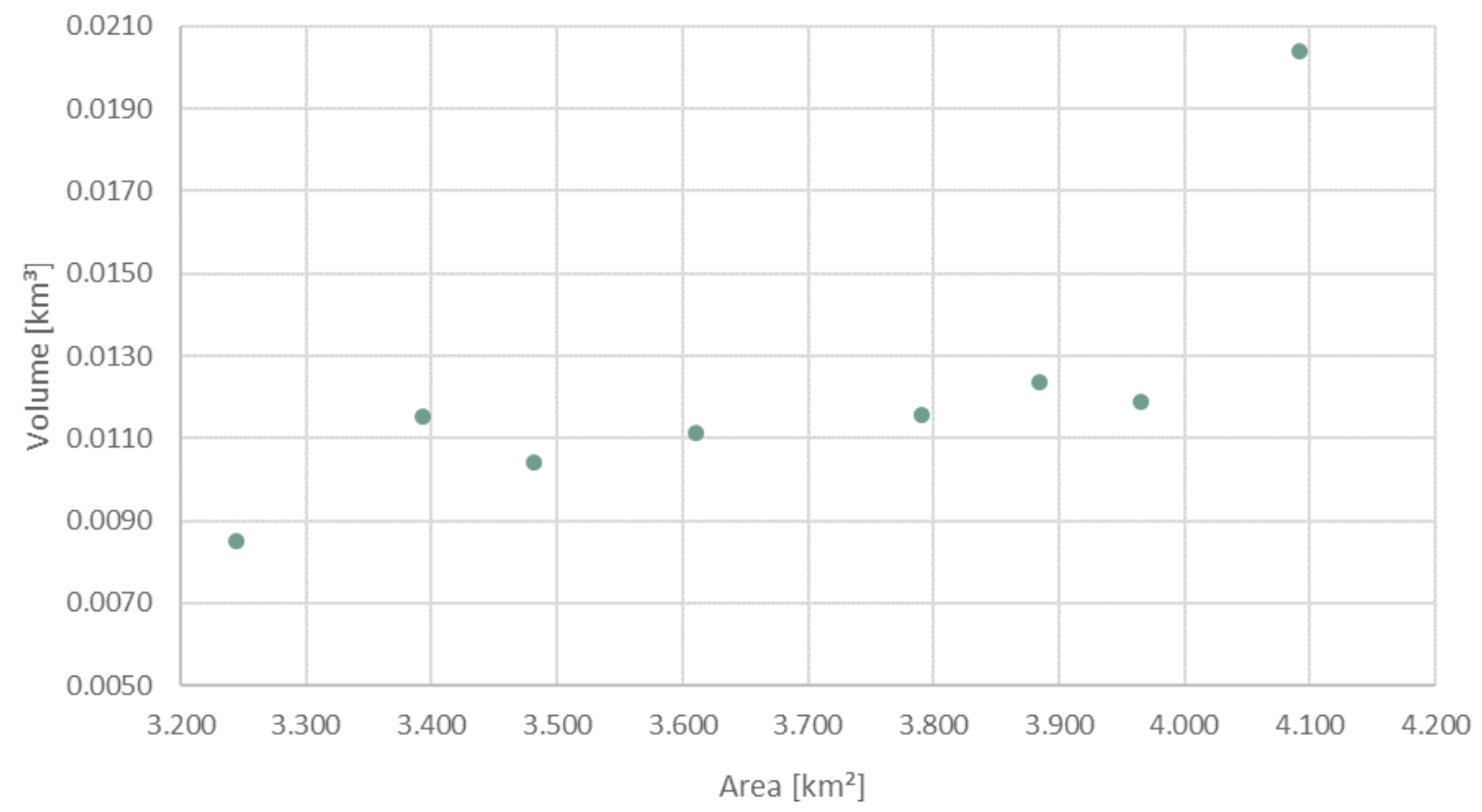

Figure 4. Comparison of the flooded area and the water retention volume for certain days of the simulated flood event in 2013.

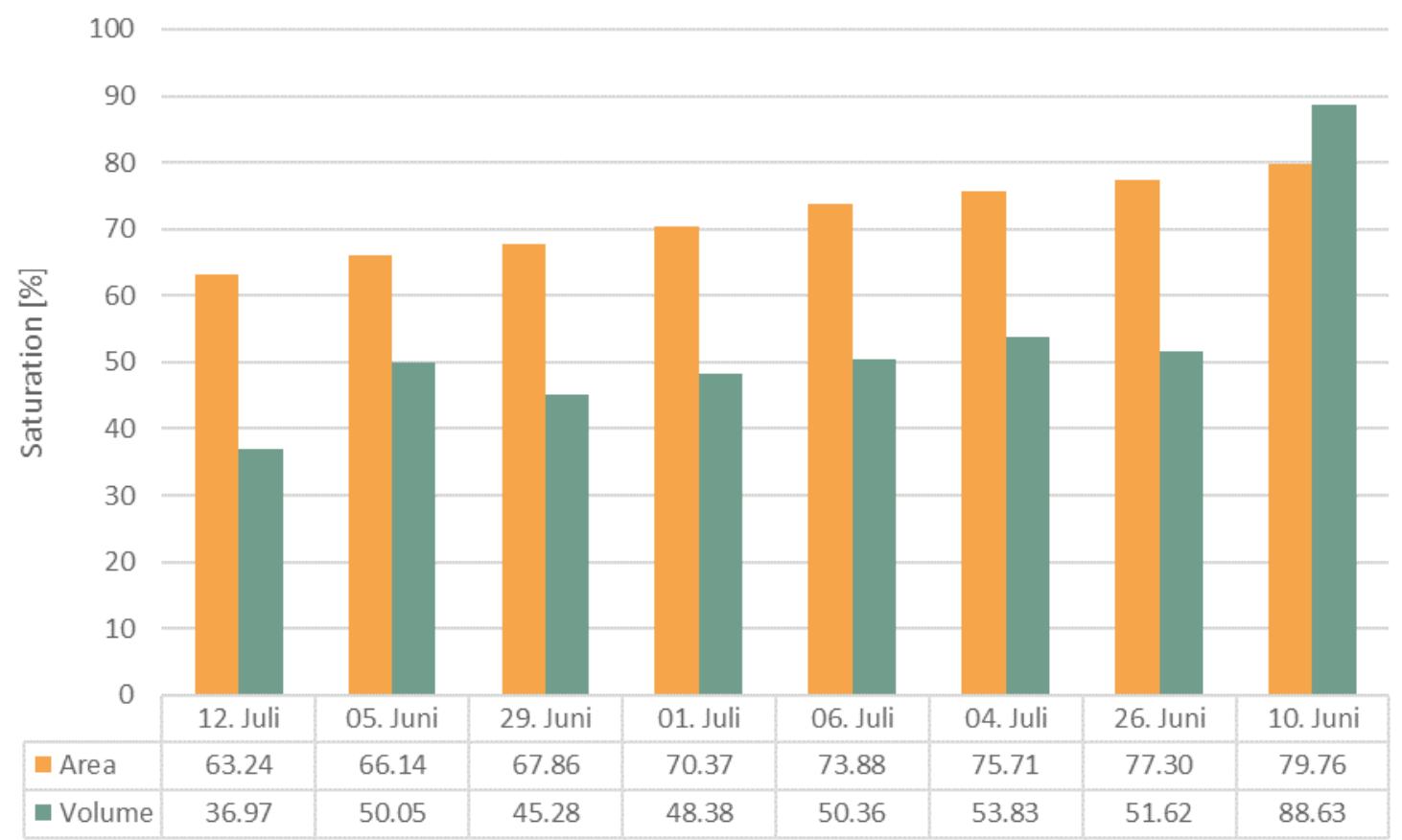

Figure 5. Exploitation of the floodplain area and volume capacity for chosen days of the simulated flood event in 2013.

from the water depth and the area in the floodplain for selected days of the flood event. Three phases can be identified. After the area is filled with water and the volume increases, the water spreads more in area than in depth. A constant volume is reached. At a certain point, the water depth and also the volume increases. This means there is a non-linear relation between the flooding area and flooding volume.
The flooded area and the water volume vary in the extent of coverage of the potential floodplain retention capacity (Figure 5). The utilisation of the floodplain area for water retention ranges between $63 \%$ and $80 \%$. In relation to that, the average exploitation of the floodplain volume is between $37 \%$ and $54 \%$ and is generally lower than the area exploitation. The volume exploitation is higher only on the 
peak day (June $10^{\text {th }}$ ) in comparison to the other days and it is only on this day that the volume exploitation is higher than the area one.

\section{Effects of different land uses}

In order to analyse the impact of different land uses on the flood regulation, the parameters of flood area and water depth are examined in Figure 6 . The percentage of the simulated mean water depth towards the total water depth is given in green. The percentage of the extent of the flooded area towards the total flooded area for each land use in the floodplain on June $10^{\text {th }} 2013$ is given in orange. As expected, the highest water columns $(6.31 \mathrm{~m})$ and largest flooded area $(2.5 \mathrm{~m})$ occur over the land use type 'water', where the surface elevation is low (middle elevation of the riverbed is about $13.7 \mathrm{~m}$ above sea level). The second highest water columns $(2.81 \mathrm{~m})$ and second extensive flooded area $(2.25 \mathrm{~m})$ are above the pasture areas. After the land use type 'water', these areas account for the largest share of flooded areas and greatest water depths. Groves have a mean water depth $(2.7 \mathrm{~m})$ which is comparable to the pastures. Figure 6 shows, that the percentage of the flooded area is higher than the water depth above the land uses pasture and water. In contrast, the percentage of the flooded depth is higher above the land use types forest and groves.

\section{Impact of extreme future flood scenarios}

The effects of a possible future higher runoff, caused by changing climate patterns, was considered for the three land use scenarios with HEC-RAS. Again, both the inundation area and the volume were evaluated (Figure 7). The green points depict the volume, while the flooded area is mapped in orange triangles. The bright symbols display the present scenarios and the dark ones show the future scenario with a $10 \%$ higher discharge compared to 2013 . The HECRAS model results indicate a decrease of the flooded area under current flood runoff conditions for the NBS1 and NBS2 compared to NBSO (light orange triangles). However, an increase in forest areas result in a higher water volume at the current run off level (light green). In contrast, the dike relocation and thus the increased floodplain area not only reduces the flooded area, but also the volume.

A flood event with $10 \%$ higher amounts of discharge (dark coloured symbols) causes both increasing water volumes and higher flood area extensions. For all three scenarios, a flooded area of $\sim 4.9 \mathrm{~km}^{2}$ and a water volume of $\sim 0.03 \mathrm{~km}^{3}$ is estimated. The differences of the water amount between the scenarios is very low compared to the current discharge. Only the dike relocation leads to a larger extension of flooded area. Furthermore, the animations indicate that in the assumed future discharge scenario, the water overflows the dikes.

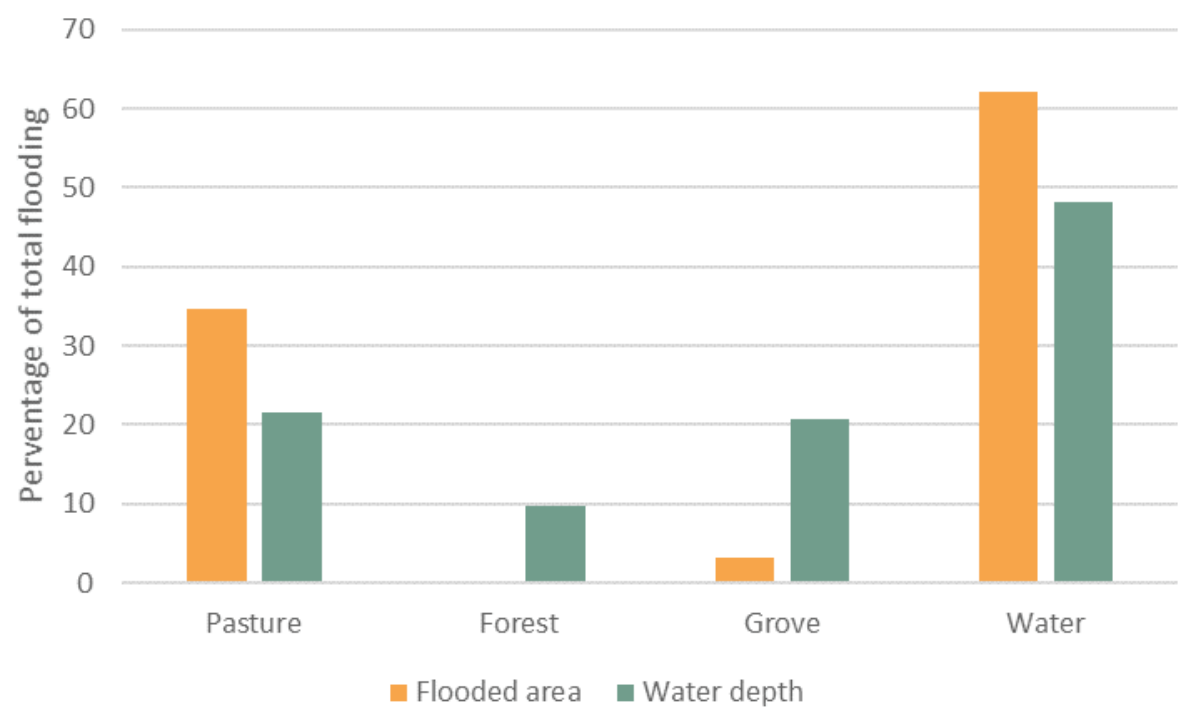

Figure 6. Water depth and flooded area by different land uses at the day with the highest water level during the simulated flood event in 2013. 


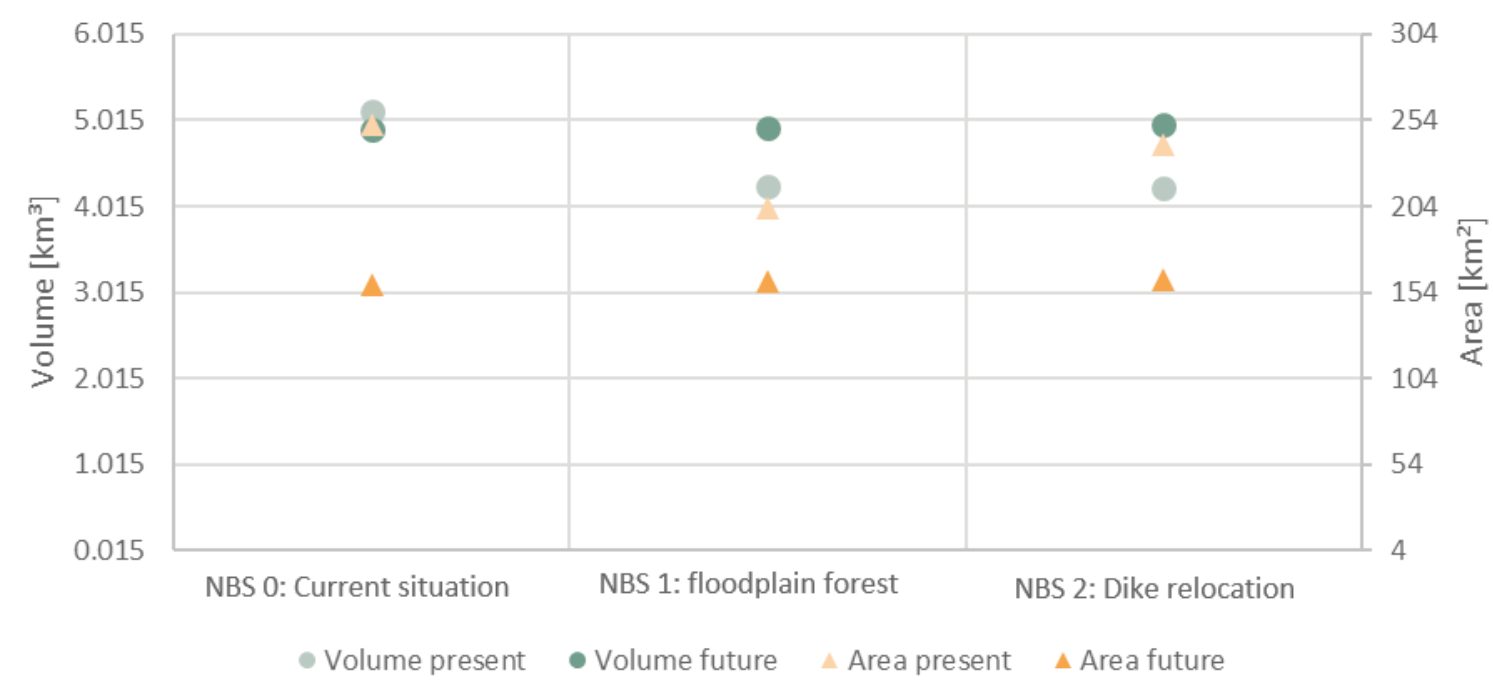

Figure 7. Flood volume and area for a high water level in 2013 and in the future with a $10 \%$ higher water level.

\subsection{FHR-Indicator}

For each land use scenario, the FHR-Indicator of the German MAES-working group was calculated in order to classify and evaluate the model results and the method. Table 2 lists the results. Derived from land use, the current retention area of the floodplain is $2.54 \mathrm{~km}^{2}$. According to the indicator values, a land use change from pasture to forest does not lead to a change of the flood retention area capacity compared to the current land use scenario. The indicator value remains at $2.54 \mathrm{~km}^{2}$. Only the proportion of the land use shifts to more forests than pasture. However, this is not represented by a respective change in the indicator value. The selected scenario "dike relocation" increases the flood retention area by 0.62 $\mathrm{km}^{2}$ to $3.16 \mathrm{~km}^{2}$. This means, that the FHR-Indicator increases by $24 \%$ in this scenario compared to the other scenarios.

Table 2. Results of the FHR-indicator for the three scenarios..

\begin{tabular}{|l|c|c|c|}
\hline Scenarios & $\begin{array}{c}\text { Current } \\
\text { situation }\end{array}$ & Forest & $\begin{array}{c}\text { Dike } \\
\text { relocation }\end{array}$ \\
\hline Total $\left[\mathrm{km}^{2}\right]$ & 2.54 & 2.54 & 3.16 \\
\hline $\begin{array}{l}\text { Changing to current } \\
\text { situation [\%] }\end{array}$ & & +0 & +24.4 \\
\hline
\end{tabular}

\section{Discussion}

The comparison results of area and volume by the hydraulic model show that besides the consideration of processes that influence flood regulation, the selection of the evaluation parameter and dimension for flood retention service play an important role. The result of the HEC-RAS simulations show that water retention capacity cannot only be expressed by the flooding area, because the relation to the retained volume of water is not linear (Figure 4, Figure 5 ). With regard to the floodplain characteristics, the simulations confirm that at a certain point in time, the water level and with that, the water volume rises faster than the spread of water in an area. This means that there are different retention capacities between an area-based and a volume-based analyses approach (Figure 4), which is not considered by the approaches that use the FHR-indicator for example. In addition, the schematic representation in Figure 8 shows that the same area can store different amounts of water depending on the slope. de Groot et al. (2010) have already proposed a water volume based assessment that consider depressions and soil storage.

Land use is another aspect that is considered differently in both approaches. The model results support the findings of Karabulut et al. (2016) in which land cover has a high impact on flood formation. Above forest and groves the percentage of the water depth 


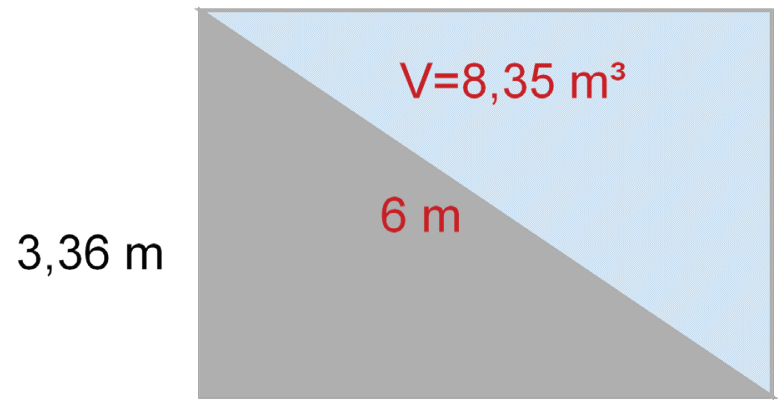

$4,97 \mathrm{~m}$

\section{$1,15 \mathrm{~m}$

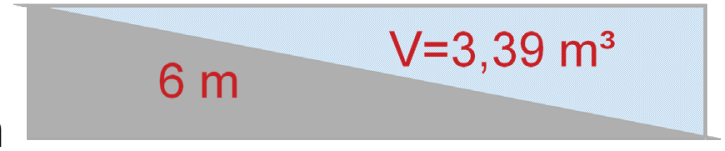 \\ $5,89 \mathrm{~m}$}

Figure 8. Schematic presentation of different volume capacities by the same area with a width of $1 \mathrm{~m}$.

is higher than the percentage of flooded area (Figure 6). Higher surface roughness by forests or groves decrease the velocities of water runoff and consequently, retain water (Figure 6, Figure 7) (Promny et al. 2015; Karabulut et al. 2016; LFU-Bayern 2018). Simoultaniously they provide an important water retention capacity to mitigate flood risks by slowing down the velocities (de Groot et al. 2010; Vallecillo et al. 2019). In contrast, pasture areas usually reduce the water level while increasing surface runoff and spreading (Karabulut et al. 2016; Promny et al. 2015). The ratio of retention in water depth is lower than by the flooded area (Figure 6).

Future flood scenarios were tested with HEC-RAS. The results confirm that flood regulation is driven by climate information. Climate affects the water cycle and so the temporal and spatial course of the flood. In this study, a future potential extreme flood event was simulated based on literature review (Alexy 2014; Nilson et al. 2014). However, the bandwidth of possible discharge rates is large and the resulting outcomes are often not robust (Nilson et al. 2014; EEA 2017). Nevertheless, the historical observations from 1980 to 2010 show an increase of the number of severe floods in Europe (EEA 2017). Alexy (2014) assumes a maximum discharge of $5000 \mathrm{~m}^{3} / \mathrm{s}$ for future runoff simulations for a study in Lenzen flood plain of the Biosphere Reserve Lower Saxonia Elbe Valley, which is directly connected to our research area. Alexy's value is comparable to our flood event peak that is $10 \%$ higher than the peak of 2013 (4700 $\mathrm{m}^{3} / \mathrm{s}$ ). Projected changes of precipitation by EURO-CORDEX and ReKliEs-DE (Jacobet al. 2014) show an increasing number of days with precipitation more than $20 \mathrm{~mm} /$ day in the Biosphere Reserve Lower Saxonia Elbe Valley. The annual change is expect- ed to be between -1 and 2 days/year (RCP2.6), 0 and 2 days/year (RCP4.5) and 0 and 3 days/year (RCP8.5; significant) (Bowyer et al. 2020). This results altered surface runoff values and illuminate the necessity to consider climate information in flood regulation ES assessments. On the other hand, climate change brings greater and longer drought periods with it in contrast to extreme flood events (Bowyer et al. 2020). Their impact on ecosystem services must also be considered in the future (Gaglio et al. 2019).

When considering climate change impacts on the water cycle especially on higher flood peaks, the simulation of an intensified flood event shows a higher extension of the flooded area and higher water columns over parts of the flooded land (Figure 7). The current retention capacity in the research area is not sufficient to handle flood events in this dimension. Concerning the chosen NBS, both selected flood regulation measures fail if a limit water level is exceeded. As a result, areas and settlements behind the dikes would be flooded. In addition, the small variation in flooded area and volume with higher water levels between the different NBS also shows that the effect of the measurements, compared to the current landscape situation, is very small.

Besides the considered processes in the hydraulic modelling (surface water storage in depressions and regulation by the roughness of land use) other landscape functions and processes also play an important role for flood regulation. The interception capacity and imperviousness are land use characteristics that affect surface runoff (Burkhard and Maes 2017). Terrain and slope are essential landscape features that influence water flow paths and velocities (Nedkov and Burkhard 2012). The dike relocation demonstrates the change in flow conditions due to altered 
terrain conditions. Technical and morphological flow barriers (in this case dikes) are important flood regulating factors that influence water flow path, velocity and direction (Niedersächsischer Landesbetrieb für Wasserwirtschaft, Küsten- und Naturschutz (NLWKN) 2017; NLWKN 2017). Terrain also influences infiltration capacities. Steeper slopes lead to a faster runoff by higher elevation differences and so to a smaller time period for infiltration (Burkhard and Maes 2017), while being able to absorb higher water columns in depressions (Figure 8). Another important limiting factor for flood regulation ES supply, which was not considered in this study, is the water holding capacity of soils (Liu et al. 2013). Infiltration and permeability are two of the main processes that influence the soil water storage capacity and retention function (Nedkov and Burkhard 2012). In addition, flood hazards and associated flood regulation ES supply depend on the type of rainfall, the intensity, the location, the duration as well as the spatial distribution (Nedkov and Burkhard 2012; Stürck et al. 2014).

Both methods have some limitations that should to be mentioned. Hydraulic modelling can simulate flood area and water volume retention and offers the possibility to test different scenarios and input data sets such as land use change or climate-induced change (Grizzetti et al. 2015; Grizzetti et al. 2016). Burkhard and Maes (2017, p.100) mention, "for regulating services, modelling is sometimes the only option in order to quantify actual ecosystem service flows". Nedkov and Burkhard (2012, p.71) add to this "[...] hydrologic models can be used to quantify indicators that represent the flood prevention function of ecosystems". However, due to limited data availability and the complexity of nature and physical processes, simplifications must be made in general and also for the specific research area.

For example, during the flood of 2013, areas behind the dike were also flooded. This may have been caused by high groundwater levels, exceeding the water absorption capacity, or by high precipitation rates (Rannow and Warner 2016; Mosbrugger et al. 2012). The applied hydraulic HEC-RAS model does not consider these processes and only indicates the surface runoff. With the assumption of a high groundwater level and a negligible unsaturated zone, which is typical for river flood plains, infiltration is of minor importance. In view of the research questions, a more complex approach is not useful. This requires a more comprehensive and not available data basis. Furthermore, the applied area based FHR-indicator of the MAES-DE working group refers also to the surface based retention performance. Therefore, the exclusive focus on surface runoff with the HEC-RAS simulation covers the main hydraulic effects of surface flood retention and allows the comparison with the FHR-indicator.

In contrast, the area based FHR-indicator provides an easy method to estimate the availability and development of floodplain areas on the national scale. Advantage are the low data requirements and the simple calculation process. However, the method misses some crucial flood retention functions as vegetation roughness and volume surface water storage capacity. Functionality and sufficient capacity under future climate conditions cannot be tested by this approach (Table c).

When comparing these two methods, it must be mentioned that both were developed for different scales and to answer different questions. While the modelling approach is best suited for local to regional scales and can generate detailed output, the FHR-indicator by the MAES-working group was designed for the national scale (Grunewald et al. 2016). However, we applied the indicator on the local level in our study. Flood retention is particularly relevant locally and serves to protect the population. The retention area of the floodplain can be calculated by the approach of the FHR-indicator and was used in this study to classify and evaluate the results by the hydraulic modelling approach.

The pressure climate change on flood regulation ES is used indirectly as a time variable input by runoff values. Changed precipitation patterns indicate a change in the local water cycle, which influences runoff. If a preceding hydrological model (e.g. HECHMS) is used, climate data are used as drivers to calculate discharge parameters as input for the hydraulic model. Changed climate conditions must be taken into account in the assessment of flood-regulation ES. The FHR-indicator represents the current flood area capacity. Climate as pressure of insufficient capacity can not be considered. 


\section{Conclusions and outlook}

Flood regulation ES supply is complex and determined by many natural and anthropogenic drivers and processes. Land use, climate change, terrain and soil are some of the main influencing factors. With the hydraulic Model HEC-RAS, surface retention ES, can be determined for current and future discharge scenarios. In contrast, the FHR-indicator is merely based on the area regardless of other locally detailed factors and cannot provide estimations about future functionality of the floodplain.

This study focus on hydraulic surface retention functions and the water spreading in the area and volume. The application of hydrological models in a continuative research approach offers the possibility to consider infiltration and interception processes more effectively to estimate temporal and spatial variations of runoff. This is an interesting and important approach to increase the knowledge of flood regulation ES and to investigate the importance of soil and vegetation retention. Through this extended approach, regional climate information could also be directly included in the analysis.

The results of this study already show the impact of climate information via the water cycle. This information is necessary to estimate future flood regulation ES potentials and capacities, for example, to test land use scenarios for future suitability. With respect to climate change, the importance of ES that regulate the effects of flooding will increase in the future due to expected changes of all water cycle components. To cover as many future flood scenarios as possible and to test the functionality of the flood regulation ES, it is useful to consider a bandwidth of climate simulations.

\section{References}

AdV (Arbeitsgemeinschaft der Vermessungsverwaltungen der Länder der Bundesrepublik Deutschland) 2018. Dokumentation zur Modellierung der Geoinformationen des amtlichen Vermessungswesens, ATKIS-Objektartenkatalog Basis-DLM, 408pp.

Albert, C., Burkhard, B., Daube, S., Dietrich, K., Engels, B., Frommer, J., Götzl, M., GrêtRegamey, A., Job-Hoben, B., Keller, R., Marzelli, S., Moning, C., Müller, F., Rabe, S.-E., Ring, I., Schwaiger, E., Schweppe-Kraft, B., Wüstemann, H. 2015. Empfehlungen zur Entwicklung bundesweiter Indikatoren zur Erfassung von Ökosystemleistungen, Diskussionspapier. BfN, Bonn- Bad Godesberg, 53 Seiten.

Alexy, M. 2014. Zweidimensionale hydronumerische Modellierung des Abflussgeschehens der Elbe. In: Prüter, J.; Keienburg, T.; Schreck, C., Klimafolgenanpassung im Biosphärenreservat Niedersächsische Elbtalaue - Modellregion für nachhaltige Entwicklung, TuTech Verl., Hamburg, 162pp.

ARIES n.d. ARtificial Intelligence for Ecosystem Services. http://aries.integratedmodelling.org/ [accessed 11 December 2019].

Baessler, C., Klotz, S. 2019. Introduction to Part II: Drivers and Their Risks for Ecosystems, Their Functions, and Services. In: Schröter, M.; Bonn, A.; Klotz, S.; Seppelt, R.; Baessler, C., Atlas of Ecosystem Services, Springer, Cham, Switzerland, 414pp.

Bender, S., Bülow, K. 2018. Klimawandel und Wasserversorgung: Folgen, Risiken und Anpassungsbedarf. DVGW.

Bender, S., Jacob, D. 2016. Die Aussagekraft von Klimaprojektionen für zukünftige Herausforderungen der Trinkwasserversorgung in Deutschland. gwf-Wasser. 
BGR 2013. Bodenübersichtskarte der Bundesrepublik Deutschland 1:100 000, Bundesanstalt für Geowissenschaften und Rohstoffe, Hannover.

Bowyer, P., Pfeifer, S., Preuschmann, S., El-Zohbi, J., Korhonen, N., Tomozeiu, R., Spyrou, C., Thomson, C., Basu, B., Zieher, T. 2020. Report on baseline weather and future climate conditions for all OAL sites. OPERANDUM Public Deliverable 5.1, Horizon 2020 OPERANDUM Project under the Grant Agreement No 776848, 167. https://www. operandum-project.eu/wp-content/uploads/ D5.1_Report_baseline_weather_future_climate_ conditions_OAL.pdf.

BrNE-Management (Biosphärenreservatsverwaltung Niedersächsische Elbtalaue) 2009. Biosphärenreservatsplan Niedersächsische Elbtalaue, 316pp.

Brunner, G.W. 2016a. HEC-RAS 2D Modeling User's Manual, CPD-68A, 171pp.

Brunner, G.W. 2016b. HEC-RAS Applications Guide, 519pp.

Brunner, G.W. 2016c. HEC-RAS Hydraulic Reference Manual, 538pp.

Brunner, G.W. 2016d. HEC-RAS User's Manual, CPD68, 960pp.

Burkhard, B., Maes, J. 2017. Mapping Ecosystem Service, Pensoft Publishers, Sofia, 374pp.

Chow, V.T. 1959. Open Channel Hydraulics, McGrawHill Book Company, New York.

de Groot, R.S., Alkemade, R., Braat, L., Hein, L., Willemen, L. 2010. Challenges in integrating the concept of ecosystem services and values in landscape planning, management and decision making. Ecological Complexity 7, 260-272. doi:10.1016/j.ecocom.2009.10.006.

DKRZ (Deutsches Klimarechenzentrum) n.d. Die Szenarien. https://www.dkrz.de/media/ klimasimulationen/ipcc-ar5/die-szenarien [accessed 28 November 2019].
EEA (European Environment Agency) 2017. Climate change, impacts and vulnerability in Europe 2016, An indicator-based report, Luxembourg, 419 Seiten, URL: http://www.eea.europa.eu/ publications/climate-change-impacts-andvulnerability-2016/at_download/file.

Engel, S., Schaefer, M. 2013. Ecosystem services-a useful concept for addressing water challenges? Environmental Sustainability 5, 696-707. doi:10.1016/j.cosust.2013.11.010.

European Commission 2011. our life insurance, our natural capital: an EU biodiversity strategy to 2020.

European Commission 2015. Nature-Based Solutions \& Re-Naturing Cities, Final Report of the Horizion 2020 Expert Group on 'Nature-Based Solutions' and Re-Naturing Cities', European Union, Luxembourg, 74pp.

Gaglio, M., Aschonitis, V., Pieretti, L., Santos, L., Gissi, E., Castaldelli, G., Fano, E.A. 2019. Modelling past, present and future Ecosystem Services supply in a protected floodplain under land use and climate changes. Ecological Modelling 403, 23-34. doi:10.1016/j.ecolmodel.2019.04.019.

Grizzetti, B., Lanzanova, D., Liquete, C., Reynaud, A. 2015. Cook-book for water ESS assessment and valuation. JRC Technical Reports, 136pp.

Grizzetti, B., Lanzanova, D., Liquete, C., Reynaud, A., Cardoso, A.C. 2016. Assessing water ecosystem services for water resource management. Environmental Science \& Policy 61, 194-203. doi:10.1016/j.envsci.2016.04.008.

Grunewald, K., Herold, H., Meinel, G., Richter, B., Syrbe, R.-U., Marzelli, S., Szüc, L., Walz, U. 2016. Ökosystemleistungen Deutschlands, Indikatoren für ein bundesweites Assessment und Monitoring, 231pp.

IKSE (Internationale Kommission zum Schutz der Elbe) n.d. Hydrologische Auswertung des Hochwassers vom Juni 2013 im Einzugsgebiet der Elbe. 
IPCC (Stocker, T.F.; Qin, D.; Plattner, G.-K.; Tignor, M.; Allen, S.K. 2013. Climate change 2013, The physical science basis. Contribution of Working Group I to the Fifth Assessment Report of the Intergovernmental Panel on Climate Change, Cambridge University Press, United Kingdow and New York, 1535 pages.

IPCC 2019. Climate Change and Land, An IPCC Special Report on climate change, desertification, land degradtation, sustainable land management, food security, and greenhouse ggas fluxes in terrestrial ecosystems.

Jacob, D., Petersen, J., Eggert, B., Alias, A., Christensen, O.B., Bouwer, L.M., Braun, A., Colette, A., Déqué, M., Georgievski, G., Georgopoulou, E., Gobiet, A., Menut, L., Nikulin, G., Haensler, A., Hempelmann, N., Jones, C., Keuler, K., Kovats, S., Kröner, N., Kotlarski, S., Kriegsmann, A., Martin, E., van Meijgaard, E., Moseley, C., Pfeifer, S., Preuschmann, S., Radermacher, C., Radtke, K., Rechid, D., Rounsevell, M., Samuelsson, P., Somot, S., Soussana, J.-F., Teichmann, C., Valentini, R., Vautard, R., Weber, B., Yiou, P. 2014. EUROCORDEX: new high-resolution climate change projections for European impact research. Regional Environmental Change 14, 563-578. doi:10.1007/s10113-013-0499-2.

Karabulut, A., Egoh, B.N., Lanzanova, D., Grizzetti, B., Bidoglio, G., Pagliero, L., Bouraoui, F., Aloe, A., Reynaud, A., Maes, J., Vandecasteele, I., Mubareka, S. 2016. Mapping water provisioning services to support the ecosystem-waterfood-energy nexus in the Danube river basin. Ecosystem Services 17, 278-292. doi:10.1016/j. ecoser.2015.08.002.

LBEG (Landesamt für Bergbau, Energie und Geologie) n.d. Kartendienste (Web Layer Services) des LBEG. http://www.lbeg.niedersachsen. de/kartenserver/web_map_services_wms/ kartendienste-web-map-services-deslbeg-91769.html [accessed 10 July 2018].

LFU-Bayern (Bayrisches Landesamt für Umwelt) 2018. Entstehung von Hochwasser. https://www. Ifu.bayern.de/wasser/hw_entstehung/index.htm [accessed 06 December 2018].
Liu, S., Crossman, N.D., Nolan, M., Ghirmay, H. 2013. Bringing ecosystem services into integrated water resources management. Journal of environmental management 129, 92-102. doi:10.1016/j. jenvman.2013.06.047. [in eng].

Logsdon, R.A., Chaubey, I. 2013. A quantitative approach to evaluating ecosystem services. Ecological Modelling 257, 57-65. doi:10.1016/j. ecolmodel.2013.02.009.

MEA (Millennium Ecosystem Assessment) 2005. Ecosystems and human well-being, Synthesis, Island Press, Washington DC, x, 137.

Meyer, T. 2017. Ökologie mitteleuropäischer Flussauen, Springer Berlin Heidelberg, Berlin, Heidelberg, 166pp.

Mosbrugger, V., Brasseur, G., Schaller, M., Stribrny, B. 2012. Klimawandel und Biodiversität, Folgen für Deutschland, Darmstadt.

Moss, R.H., Edmonds, J.A., Hibbard, K.A., Manning, M.R., Rose, S.K., van Vuuren, D.P., Carter, T.R., Emori, S., Kainuma, M., Kram, T., Meehl, G.A., Mitchell, J.F.B., Nakicenovic, N., Riahi, K., Smith, S.J., Stouffer, R.J., Thomson, A.M., Weyant, J.P., Wilbanks, T.J. 2010. The next generation of scenarios for climate change research and assessment. Nature 463, 747-756. doi:10.1038/ nature08823. [in eng].

Müller, F., Burkhard, B., Hou, Y., Ma, L. 2016. Handbook on Ecosystem Services, Indicators for Ecosystem Services, 20pp.

Nedkov, S., Burkhard, B. 2012. Flood regulating ecosystem services-Mapping supply and demand, in the Etropole municipality, Bulgaria. Ecological Indicators 21, 67-79. doi:10.1016/j. ecolind.2011.06.022.

Niedersächsischer Landesbetrieb für Wasserwirtschaft, Küsten- und Naturschutz (NLWKN) 2017. Abflussverbessernde Maßnahmen an der Unteren Mittelelbe.

Nilson, E., Krahe, P., Klein, B., Lingemann, I., Horsten, T., Carambia, M., Larina, M., Maurer, T. 2014. Auswirkungen des Klimawandels auf das Abflussgeschehen und die Binnenschifffahrt in Deutschland, Schlussbericht KLIWAS-Projekt 4.01, 90pp. 
NLWKN (Niedersächsischer Landesbetrieb für Wasserwirtschaft, Küsten- und Naturschutz) 2017. Abflussverbessernde Maßnahmen an Unteren Mittelelbe, Rahmenplan, 64pp.

Oesterwind, D., Rau, A., Zaiko, A. 2016. Drivers and pressures - Untangling the terms commonly used in marine science and policy. Journal of environmental management 181, 8-15. doi:10.1016/j.jenvman.2016.05.058. [in eng].

Paprotny, D., Sebastian, A., Morales-Nápoles, O., Jonkman, S.N. 2018. Trends in flood losses in Europe over the past 150 years. Nature communications 9, 1985. doi:10.1038/s41467018-04253-1. [in eng].

Pfeifer, S., Bülow, K., Gobiet, A., Hänsler, A., Mudelsee, M., Otto, J., Rechid, D., Teichmann, C., Jacob, D. 2015. Robustness of Ensemble Climate Projections Analyzed with Climate Signal Maps: Seasonal and Extreme Precipitation for Germany. Atmosphere 6, 677-698. doi:10.3390/ atmos6050677.

Promny, M., Hammer, M., Hatz, M., Busch, N. 2015. 2D-Modellierung an der unteren Mittelelbe zwischen Wittenberge und Geesthacht, Beschreibung der Strömungsverhältnisse und Wirkung von abflussverbessernden Maßnahmen auf Hochwasser der Elbe. Bundesanstalt für Gewässerkunde (BfG), 209pp.

Rannow, S., Warner, B. 2016. Anpassung an den Klimawandel als Herausforderung für Biosphärenreservate-dasBeispiel Flusslandschaft Elbe-Brandenburg. Raumforschung und Raumordnung 74, 555-567. doi:10.1007/s13147016-0425-4.

Sharp, R., Chaplin-Kramer, R., Wood, S., Guerry, A., Tallis, H., Ricketts, T., Nelson, E., Ennaanay, D., Wolny, S., Olwero, N., Vigerstol, K., Pennington, D., Mendoza, G., Aukema, J., Foster, J., Forrest, J., Cameron, D., Arkema, K., Lonsdorf, E., Kennedy, C., Verutes, G., Kim, C.K., Guannel, G., Papenfus, M., Toft, J., Marsik, M., Bernhardt, J., Griffin, R., Glowinski, K., Chaumont, N., Perelman, A., Lacayo, M., Mandle, L., Hamel, P., Vogl, A.L., Rogers, L., Bierbower, W., Denu, D., Douglass, J. 2018. InVEST User's Guide, Intergrated Caluation of Ecosysstem Services and Tradeoffs. The Natural Capital Project.
Sitterson, J., Knightes, C., Parmar, R., Wolfe, K., Mulche, M., Avant, B. 2017. An Overview of Rainfall-Runoff Model Types. United States Environmental Protection Agency (EPA), 30pp.

Stürck, J., Poortinga, A., Verburg, P.H. 2014. Mapping ecosystem services: The supply and demand of flood regulation services in Europe. Ecological Indicators 38, 198-211. doi:10.1016/j. ecolind.2013.11.010.

Swiss Re Institute 2019. Natural catastrophes and man-made disasters in 2018: "secondary" perils on the frontline, URL: https://www.swissre. com/dam/jcr:c37eb0e4-c0b9-4a9f-99543d0bb4339bfd/sigma2_2019_en.pdf (accessed 18 Dec 2019).

TEEB 2010. Die Ökonomie von Ökosystemen und Biodiversität, Die ökonomische Bedeutung der Natur in Entscheidungsprozesse integrieren. Ansatz, Schlussfolgerung und Empfehlungen von TEEB - eine Synthese, Münster, 48pp.

Vallecillo, S., La Notte, A., Kakoulaki, G., Kamberaj, J., Robert, N., Dottori, F., Feyen, L., Rega, C., Maes, J. 2019. Ecosystem services accounting, Pilot accounts for crop and timber provision, global climate regulation and flood control. JRC Technical Reports, 165pp.

van Vuuren, D.P., Edmonds, J., Kainuma, M., Riahi, K., Thomson, A., Hibbard, K., Hurtt, G.C., Kram, T., Krey, V., Lamarque, J.-F., Masui, T., Meinshausen, M., Nakicenovic, N., Smith, S.J., Rose, S.K. 2011. The representative concentration pathways: an overview. Climatic Change 109, 5-31. doi:10.1007/s10584-011-0148-z.

Vigerstol, K.L., Aukema, J.E. 2011. A comparison of tools for modeling freshwater ecosystem services. Journal of environmental management 92, 24032409. doi:10.1016/j.jenvman.2011.06.040. [in eng].

WEF (World Economic Forum) 2019. The Global Risks Report 2019, 14th Edition, 114pp.

WWAP (United Nations World Water Assessment Programme / UN-Water) 2018. The United Nations World Water Development Report 2018: Nature-Based Solutions for Water, UNESCO, Paris, France. 
WWF (World Wildlife Fund) 2016. Natural and

Nature-based flood management: a green guide.

\section{Appendix}

Table a. Overview of the used dataset.

\begin{tabular}{|l|l|c|c|l|}
\hline Data & Type and spatial resolution & $\begin{array}{l}\text { Used for } \\
\text { indicator }\end{array}$ & $\begin{array}{c}\text { Used for } \\
\text { HEC-RAS }\end{array}$ & Sources \\
\hline $\begin{array}{l}\text { Digital elevation } \\
\text { model (DEM) }\end{array}$ & Raster; 1 m & $\mathrm{x}$ & Biosphere reserve management (2018) \\
\hline Land use & Vector; ATKIS-Basis DLM (AdV 2018) & $\mathrm{x}$ & $\mathrm{x}$ & $\begin{array}{l}\text { Biosphere reserve management (2018) } \\
\text { (AdV 2018) }\end{array}$ \\
\hline Run-off data & $\begin{array}{l}\text { Historical measurements of a gauge } \\
\text { nearby (57 days, daily resolution); } \\
\text { future projections of the discharge } \\
\text { behaviour }\end{array}$ & $\mathrm{x}$ & (IKSE n.d.; Nilson et al. 2014) \\
\hline $\begin{array}{l}\text { Roughness coefficients } \\
\text { (Manning) }\end{array}$ & \begin{tabular}{l} 
Look-up table (see Table 1) \\
\hline
\end{tabular}
\end{tabular}

Table b. Description of the land use scenarios.

\begin{tabular}{|l|l|}
\hline Scenario & Description \\
\hline $\begin{array}{l}\text { Reference scenario: } \\
\text { current situation (NBS 0) }\end{array}$ & Current situation with pastures and water bodies as main land uses within the floodplain. \\
\hline NBS 1- floodplain forest & $\begin{array}{l}\text { A land use change from pastures to forest changes the roughness and so the velocity and water } \\
\text { balance. It is a typical natural measure in run-off management (WWAP 2018; WWF 2016). The } \\
\text { areal extension of the floodplain does not change by this measure. }\end{array}$ \\
\hline NBS 2 - dike relocation & $\begin{array}{l}\text { A dike relocation on the southern site of the Elbe river increases the recent floodplain from 5.13 } \\
\text { km² to 7.32 } \mathrm{km}^{2} \text {. The additional area is used as pastures. It is a common method to recover old } \\
\text { floodplain areas (WWAP 2018; WWF 2016). This measure is supposed to improve natural processes } \\
\text { and to increase the resilience against flooding of the surrounding areas. }\end{array}$ \\
\hline
\end{tabular}

Table c. Advantages and limitations of the methods (FHR-indicator and hydraulic modelling with HEC-RAS) to estimate flood regulation services.

\begin{tabular}{|c|c|c|}
\hline & Ecosystem service FHR-indicator & Hydraulic modelling with HEC-RAS \\
\hline \multirow{3}{*}{ 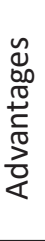 } & Easy-to-communicate values & $\begin{array}{l}\text { Including crucial parameters and processes such as: terrain elevations, } \\
\text { hydrographs (observation and future assumptions), land cover for } \\
\text { roughness, dike location and other barriers with heights }\end{array}$ \\
\hline & Simple and easy to calculate & Simulation of long time periods as well as single events \\
\hline & Small data set required & Easy-to-use hydraulic model with little input data \\
\hline \multirow{3}{*}{ 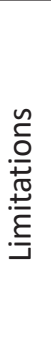 } & $\begin{array}{l}\text { Misses some crucial factors such as soil } \\
\text { conditions (infiltration), additional land cover } \\
\text { characteristics (roughness and interception), } \\
\text { terrain conditions, climate information }\end{array}$ & $\begin{array}{l}\text { More complex in handling and in data requirements (in comparison to the } \\
\text { FHR-indicator). Not all boundary conditions are available }\end{array}$ \\
\hline & $\begin{array}{l}\text { Based on used data, no conclusion is possible } \\
\text { regarding to the limits of retention capacity }\end{array}$ & $\begin{array}{l}\text { Comparison of results is more complex because more analysis and } \\
\text { calculations are needed }\end{array}$ \\
\hline & & $\begin{array}{l}\text { No input of soil and geology data (e.g. type, thickness of the unsaturated } \\
\text { zone, groundwater levels) and so no modelling of infiltration }\end{array}$ \\
\hline
\end{tabular}

